\title{
MODIFIED GAUNILO-TYPE OBJECTIONS AGAINST MODAL ONTOLOGICAL ARGUMENTS
}

\author{
DANIEL CHLASTAWA
}

University of Warsaw

\begin{abstract}
Modal ontological arguments are often claimed to be immune to the «perfect island» objection of Gaunilo, because necessary existence does not apply to material, contingent things. But Gaunilo's strategy can be reformulated: we can speak of non-contingent beings, like quasi-Gods or Evil God. The paper is intended to show that we can construct ontological arguments for the existence of such beings, and that those arguments are equally plausible as theistic modal argument. This result does not show that this argument is fallacious, but it shows that it is dialectically ineffective as an argument for theism.
\end{abstract}

\section{CLASSICAL AND MODAL ONTOLOGICAL ARGUMENTS}

In Proslogion II, Anselm of Canterbury presented his well-known ontological argument for the existence of God. God is by definition the being than which no greater can be conceived. If we suppose that such a being does not exist, then we could imagine something greater, namely, an existent God, but that is impossible since there can be nothing greater than God. So we may conclude that God exists.

This reasoning came under instant criticism: the monk Gaunilo objected to Anselm's proof, claiming that it is fallacious, because we could use it to establish false, or at least extremely implausible consequences, like the existence of a perfect island. For if we define Atlantis as an island that is so great that no greater island can be conceived, and if we suppose that Atlantis does not exist, then we can imagine something greater than Atlantis namely, an existent Atlantis; but it is impossible, since there can be nothing greater than Atlantis. Therefore, we should conclude that Atlantis exists. 
Anselm tried to respond to Gaunilo's arguments, but his response is quite disappointing. Anselm simply assumes that God is the only being to which an ontological argument may correctly apply, and does little to support this claim. I do not say that Anselm couldn't formulate any arguments for it, but as a matter of fact, he did not formulate them.

As we know, history likes to repeat itself, and virtually the same situation was repeated five hundred years later. Descartes in his Meditations on First Philosophy presents the following argument: God is, by definition, the being having all perfections. But existence is a perfection, therefore, God exists. Meditations drew considerable critical attention from prominent intellectuals of that time, one of which was Pierre Gassendi. Gassendi objected to the Cartesian argument with an example of the perfect Pegasus: the concept of this being, among other perfections, contains existence, therefore we should be able to establish the existence of the perfect Pegasus, which is absurd. Descartes' reply to Gassendi was crude and rhetorical, mainly due to a negative personal attitude. So again the argument intended to parallel the ontological argument was neglected and treated as silly.

Such "parallel" arguments were neglected probably even more, when objections to the ontological proofs formulated by Hume and Kant were considered by many philosophers as most important and decisive: the Humean thesis that "necessary existence" is an inconsistent concept, and the Kantian dicta that existence is not a (real) predicate and that no existential statement can be analytically true.

This situation continued until the middle of the twentieth century. It was at this time when some philosophers - most notably Charles Hartshorne and Norman Malcolm - insisted that the real intention of proponents of ontological proofs, especially Anselm, was to provide a modal proof; that is, a proof of the necessary existence of God, not just existence simpliciter. Anselm's Proslogion III contains just such an overlooked argument: God is the being than which no greater can be conceived, and if we conceive that God does not exist, we could conceive some greater being - a being which cannot even be conceived not to exist, but it is in contradiction with the definition of God. So God exists and cannot even be conceived not to exist. ${ }^{1}$ Not only did Hartshorne and

\footnotetext{
${ }^{1}$ From the purely textual point of view, Anselm's main argument is non-modal, while the modal one looks like a mere corollary, which may explain why the discussion focused on the non-modal argument. Interestingly, a similar situation is in the case of Descartes:
} 
Malcolm interpret Anselm in a novel way, but they also proposed their own modal arguments based on their interpretation of Anselm. With their work, modal form was established as a standard for contemporary ontological arguments, like those of Kurt Gödel and Alvin Plantinga.

The main hope of adherents of modal ontological arguments is the alleged ability of those arguments to avoid the main criticisms levelled against classical, non-modal proofs. Firstly, Kant's objection that existence is not a predicate may be dismissed by observing that although existence is not a predicate of anything, necessary existence is a genuine predicate, because it expresses the certain mode of existence of a certain thing. Secondly, a new light is thrown upon the rejection of the "explosivist" arguments of Gaunilo and Gassendi. Although Anselm and Descartes gave very unclear and unconvincing answers to those arguments, we can now see what probably was the intuition lying behind those answers: examples of the greatest conceivable island or perfect Pegasus do not constitute sound objections to modal ontological proofs, because the notion of necessary existence does not apply to material things, bounded in space and time and causally dependent in their existence on other things. "Necessary existing island" and "necessary existing Pegasus" are simply inconsistent concepts, so we do not have to bother with them. Malcolm, for example, says that a necessary being must exist timelessly, ${ }^{2}$ and islands and horses are clearly not timeless beings. (It should be noted, however, that an appeal to timelessness is not necessary. Hartshorne, for example, as a process theist holds that God is a temporal and changing being. Hartshorne's reason to reject arguments with islands and horses is the contingency of those beings. ${ }^{3}$ )

Those observations seem to support the view that modal ontological arguments are immune to classical criticisms and therefore may constitute sound proofs of the existence of God. But are they immune to any criticism? Certainly not, as even proponents of modal ontological arguments differ in views on the correct formulation of the argument; for example, Plantinga rejects the arguments of Hartshorne and Malcolm

the argument from Meditations is clearly a non-modal one (existence is a perfection), while in responses to Objections Descartes shifts to a modal form (necessary existence, which is an exclusively divine attribute, is a perfection).

${ }^{2}$ Norman Malcolm, 'Anselm's Ontological Arguments', The Philosophical Review, 69 (1960), 48.

${ }^{3}$ Charles Hartshorne, Anselm's Discovery: A Re-Examination of the Ontological Proof for God's Existence (La Salle: Open Court, 1991), p. 19. 
as insufficient. ${ }^{4}$ What is more, there is even a controversy over which attributes should be counted as perfections: most theists ("classical" ones) hold that eternality and immutability are perfections, but Hartshorne disagrees with them on this point. Naturally, modal proofs also come under attack by philosophers suspicious about any ontological arguments and philosophers opposed to any forms of proofs of God's existence. One possibility of a global criticism of modal ontological arguments is to insist on the Humean idea that the concept of necessary existence is incoherent or meaningless, but in recent years this view seems to be losing popularity due to widespread use of possible worlds semantics and the idea of transworld identity: a necessary existing object (like mathematical objects for example) is an object which exists in every possible world. We can also dispute some modal axioms used in the proofs, like axiom S5, i. e. discuss whether this axiom in the metaphysical interpretation (if something is possibly necessary, then it is necessary) is true or not, but it is a difficult issue. So those objections are far from conclusive. It may seem that we are stuck in an impasse: neither party gains a decisive advantage over the other. Are there any prospects of breaking this impasse? I think that there are.

\section{II. “EXPLOSIVIST” ARGUMENTS MODIFIED}

I believe we can find a global objection to modal ontological arguments by utilizing Gaunilo's and Gassendi's idea and modifying it so that it becomes immune to critics' objections. Critics say that necessary existence does not apply to islands, horses and so on, because they are contingent, temporal beings. So what about considering some noncontingent, non-temporal beings? Firstly, consider quasi-Gods, that is, beings which possess all perfections except some of them, for example a quasi-God which is omniscient, omnibenevolent and not omnipotent, but only very powerful. Secondly, consider the Evil God, that is, the being which is exactly alike God in every respect except of being maximally evil (omnimalevolent). ${ }^{5}$ The concepts of such beings cannot be dismissed

${ }^{4}$ Alvin Plantinga, The Nature of Necessity (Oxford: Clarendon Press, 1978), pp. 212-213.

${ }^{5}$ It should be noted that this line of argument is not entirely new, for among critics of ontological arguments one can find various appeals to "anti-gods" or "devils". For example, Jan Woleński (Jan Woleński, 'Gaunilon dzisiaj, in Dowody ontologiczne. W 900. rocznicę śmierci św. Anzelma, ed. Stanisław Wszołek [Kraków: Copernicus Center Press, 2011], p. 33) makes use of the concept mirroring Anselms' definition of God: the being than which no worse can be conceived. However, it is not specified what attributes this 
out of hand as inconsistent with the property of necessary existence, so they are genuine counterexamples which should be taken into serious consideration by anyone who thinks that he or she is in a possession of a sound ontological argument. To avoid any misunderstandings, I want to stress that Evil God is not the same thing as Devil or Satan, because Devil is not conceived as omnipotent and omniscient, but only as powerful and very informed. This is very important, because belief in the existence of Devil is inherent in many theistic conceptions, so many theists could be pretty happy should this belief be proved. On the contrary: if we could prove the existence of Evil God - not Devil - along with the existence of God, then we would fall into some sort of manicheism, which is unacceptable for most theists. I shall return to this issue later.

So far, we have the concepts of quasi-Gods and of the Evil God. Now, we can launch any of the modal ontological arguments to "prove" that those beings necessarily exist. Since it would take a lot of time to test all modal ontological arguments, we may choose one example to see the core idea: the reasoning goes on in an analogous way in the case of other arguments. Let's utilize one of the arguments from Malcolm it is probably the simplest one and is not engaged in any complicated formalism. The standard argument for God goes as follows:

(Premise 1) God is an eternal, and therefore noncontingent being, so it either exists necessarily, or its existence is impossible.

(Premise 2) God is not impossible.

(Conclusion) Therefore, God exists necessarily.

The argument for Evil God is exactly parallel:

(Premise $1^{\star}$ ) Evil God is an eternal, and therefore noncontingent being, so it either exists necessarily, or its existence is impossible.

(Premise $2^{\star}$ ) Evil God is not impossible.

(Conclusion*) Therefore, Evil God exists necessarily.

Of course we can substitute Evil God with any quasi-God we please and obtain an analogous conclusion. Surely such results are unwelcome to the utmost for many people. What then can be objected to this (and similar) argument?

being possesses, and Woleński seems to conceive this being as a being which simply possesses attributes which are opposite to all of God's attributes. But such being wouldn't be the worse conceivable being - for example, an omnimalevolent being which lacks omniscience is certainly per saldo less evil than an omnimalevolent being which is omniscient. In fact, the being than which no worse can be conceived - Evil God - differs with God only with respect to goodness. 


\section{OBJECTIONS TO MODIFIED GAUNILO-TYPE ARGUMENTS}

\section{"Cooked Up" Concepts}

It is sometimes claimed that the concepts of quasi-Gods, nearly perfect beings and so on are "cooked up"; that is, they are arbitrary concepts made up ad hoc by philosophers, in contrast with the concept of God, which is fairly natural. This objection could possibly be employed by Malcolm, who does not intend to prove the possibility of God and finds it sufficient to observe that the concept of God, like the concept of material thing, has "a place in the thinking and the lives of human beings". Although Malcolm, a pupil of Wittgenstein, does not say it explicitly, he is probably making use of the concept of a language game: theism is a certain language game of many people, which somehow substantiates the view that the concept of God is consistent. Perhaps he would be tempted to say that the concepts of pseudo-Gods are not anchored in this way, so they are ad hoc. But Malcolm says that "I do not think that it is legitimate to demand such a demonstration [of the consistency of the concept of God]", 7 so we could similarly reject any demand of proving the consistency of concepts of pseudo-Gods.

Another problem with Malcolm's remark is that if we treat the appeal to a theistic language game really seriously, then we could argue not only that God is possible, but that He is real, since He plays such an enormous role in the thinking and the lives of so many human beings. And this strategy would remove the very need for an ontological argument for God's existence. Since such a "linguistic argument" for God's existence looks implausible, the appeal to language games in establishing the consistency of theism also seems unconvincing. Maybe Malcolm wouldn't deny this consequence, but if so, he would be unable to formulate a convincing linguistic argument for the inconsistency of pseudo-Gods. Without deciding whether this interpretation of Malcolm is sound or not, we can say that this line of argument is amiss. Firstly, the concept of Evil God is not so arbitrary, because it has some grounds in the religious life of humanity, like that of manicheists and maltheists. Secondly, and more importantly, it is completely irrelevant whether concepts are natural or not, cooked up or not. Even the most cooked

${ }^{6}$ Norman Malcolm, 'Anselm's Ontological Arguments', The Philosophical Review, 69 (1960), 59-60.

${ }^{7}$ Ibid., p. 60. 
up concepts have some objective features, and maybe it is an objective feature of those cooked up concepts of gods that ontological arguments really apply to them. Consider the following concept:

(C) the number identical with $2,73+\log _{4} 191^{3}-\sin \left(\cos 1,14-\log _{189} \tan 1,12\right)$

It is a completely cooked up concept! But this is irrelevant, because this concept has some objective features, like being a concept of a rational number (if this number is in fact rational) or being a concept of an irrational number (if this number is in fact irrational). Therefore it is not important whether, for example, the concept of a being which is omniscient, omnibenevolent and capable only of conjuring falls of golden coins is natural, because one of the objective features of this concept may be the applicability of the ontological argument. Besides, the naturality of concepts is, naturally, an extremely vague property.

\section{Rival Gods}

Another objection goes as follows: it is impossible that there are two or more omnipotent beings, because they would limit each other's omnipotence. This is probably true, but it only shows that by using ontological arguments we may fall into contradictions, so there is another reason to give up those arguments. If somebody would insist on saying that God exists, therefore Evil God cannot exist, we could easily turn it and say that someone could insist on saying that Evil God exists, therefore God cannot exist. But someone could retort that God is more perfect, and therefore more powerful than Evil God, so God has some kind of metaphysical priority. Such argument lays on a confusion regarding the notion of perfection. This notion is ambiguous, or maybe it has even more meanings. Perfection in the neutral sense is any property that makes some being powerful, while perfection in the axiological sense is any property which makes some being axiologically positive. In the natural language, both those notions figure under the word "perfection". For example, omnibenevolence is surely a perfection in the axiological sense, but not in the neutral sense, because benevolence has nothing to do with power. On the other hand, omnipotence, omniscience and necessary existence are perfections in the neutral sense, but not in the axiological sense, because power and knowledge may be used for very different purposes, not only for good ones, but also for evil ones. Evil God differs from God only with respect to goodness, and this is not a perfection in the neutral sense. God and Evil God are equally powerful, 
since both are omnipotent, omniscient, necessarily existing, etc., so there is no reason to think that God, as more perfect, has any priority over Evil God in the competition for existence. The ambiguity of the notion of perfection has another interesting consequence: it shows that the concept of the being possessing all perfections - God - is not as homogenous as it may seem at first glance. It seems homogenous when we treat it as a concept of a being possessing all properties of some given, natural kind (in this case, that kind is "[maximal] perfection"). But once we realize that "perfection" is ambiguous, we see that the concept of a supremely perfect being is in fact "pasted" of two completely different concepts: the concept of a being supremely perfect in the neutral sense and the concept of a being supremely perfect in the axiological sense. The concept of God is therefore not a homogenous one, because it contains properties which do not form a single, natural kind, and the opposite impression is due to the use of an ambiguous word "perfection". Of course, the lack of homogeneity is not a drawback for a concept, similarly as the lack of naturality, discussed before. But it is not wholly without importance in the case of God and ontological arguments. I suppose that the apparent homogeneity of the concept of God has some intuitive, aesthetical, or even mystical value for a theist: this concept looks so simple, uniform and elegant that it may prompt to consider it as something which is not a mere figment of our imagination, but a representation of some ultimate, simple, unsurpassable, divine metaphysical reality. Such intuitions may favour the acceptance of ontological arguments and its premises among some theists. But after the recognition of the essential heterogeneity of the concept of God, those intuitions may fade away, which may in effect increase skepticism about the correctness of ontological arguments.

\section{Inconsistency}

The third and, in my opinion, the most important objection that can be raised is that quasi-Gods and Evil God are impossible. In the premise $2^{*}$ we assume that Evil God is not impossible, but maybe we are wrong and this premise is false ${ }^{8}$ Here we enter into a tricky issue, which I will try to deal with carefully and show why this objection is wrong. Let's start

${ }^{8}$ This is the premise of a "parody" of Malcolm' argument, but exactly the same premise will be crucial in the "parodies" of the arguments of Hartshorne, Gödel and Plantinga. (I put the word "parody" in quotation marks, because those parallel arguments are intended to be serious objections, not jokes.) 
with a question, what reasons can somebody have to claim that a certain being is impossible? Of course, that reason is a proof of the impossibility: for example, we can prove that the combination of being omnipotent, omnibenevolent and knowing only geometry is plainly inconsistent, because an omnibenevolent being will use its infinite power to gain knowledge about the world to spread goodness and fight evil in the most effective way. ${ }^{9}$ But, on the other hand, the combination of being omnipotent, omniscient and not being omnibenevolent does not seem inconsistent, because, as I already said, infinite power and knowledge may be used for many different purposes, also for evil ones, including greatest possible evil. Probably we cannot prove that this concept is consistent, but the proponents of modal ontological arguments have the very same problem: they cannot prove that the concept of God is consistent, they simply assume it as an additional axiom in their deductions. So, since they cannot show that God is possible, they are in no position to claim that (for example) Evil God is impossible, unless they deliver an explicit proof of its impossibility. Is there any such proof?

Some theists support the following argument: Evil God is impossible, because as an omniscient being, it is also morally omniscient, and therefore is unable to perform any evil acts. What shall we say about this objection? Some people may be tempted to reject it on meta-ethical grounds: there is no such thing as moral knowledge, because sentences expressing moral valuations do not have any truth-value, so (by classical definition of knowledge as justified true belief) they cannot be an object of knowledge. But this objection, involving an acceptance of metaethical antirealism, noncognitivism and/or emotivism, is not the one I would support: firstly, I am committed to meta-ethical intuitionism; secondly (and more importantly, since my personal views are irrelevant in this matter), this argument is ineffective, because moral anti-realism is controversial in itself, there are no decisive arguments supporting it. So it would again put us in a philosophical impasse.

However there is a much simpler and better argument against the incompatibility of omniscience with omnimalevolence. For the sake

9 Although somebody could insist that any talk of "gaining" (implying change) is inappropriate in the case of eternal beings, we may neglect this problem, because analogous problems arise with respect to God itself: we could argue that God, as eternal and immutable being, cannot act, cannot know anything, cannot be conscious, cannot love, cannot hate, cannot judge, etc., and this would pose a very serious challenge for the consistency of theism itself. 
of the argument let's assume the existence of genuine moral knowledge. Now, the possession of moral omniscience by some subject does not imply that this subject will act in accordance with this knowledge. By rejecting this view we would fall into ethical intellectualism, which is very implausible. On its basis it seems unlikely to explain the phenomenon of weak will, when a subject knows that he or she shouldn't act in a certain way, but cannot help himself or herself, for example due to extreme lust. Another phenomenon unlikely to be explained by intellectualism is bad will itself: it seems that an ethical intellectualist should eventually endorse a view that all subjects are essentially good, but some of them (like Devil) are handicapped by a lack of moral knowledge. It would seem that even the most loathsome villain acts with a good will. Some subjects create objective evil and harm, but only because they do not know it to be so: should they realize it, they would cease doing this. It is not only counter-intuitive, but also morally dubious, for it would seem that condemnation and persecution of villains is equally unjustified as condemnation and persecution of children for their inability to solve differential equations. And if someone would retort that a villain is guilty of not acquiring appropriate moral knowledge, we will fall into a vicious regress, because we could say that he or she did not know that he or she should acquire any moral knowledge.

Those consequences of ethical intellectualism are even more destructive for the religious perspective: we should come to the conclusion that Devil - the alleged symbol of ultimate evil and corruption - is a confused, but noble mutineer, who hates God and rebelled against him, because God wrongly seems to him to be an evil tyrant and oppressor. Someone could object that phenomena of weak and bad will occur only in the case of finite and temporal beings, like humans (or even angels), not in the case of eternal beings. But the plausibility of the very attribution of such a human and temporal thing as will to eternal beings is pretty dubious, so if a theist accepts such an attribution, then there seems to be no reason to think why this will cannot be weak or bad. If we accept the possibility of infinitely good will, then acceptance of the possibility of infinitely bad will would be equally justified. What's more, it seems that moral omniscience is not only compatible with omnimalevolence, but it is also a necessary condition of the latter. For if a subject is not in a possession of moral omniscience, then it is possible that some of its evil actions are merely accidentally evil; the lack of moral omniscience may be at least a partial excuse for those actions, and the existence of 
such excuses makes omnimalevolence impossible: omnimalevolence excludes every possible excuse. A subject which performs all evil actions on purpose is worse than a subject which performs some of its evil actions unintentionally. Infinite and unsurpassable evil is possible only if some subject is in possession of complete and well-established moral knowledge and in all possible circumstances intends to act contrary to what it knows to be good and decent.

Another argument for the impossibility of Evil God employed by some theists goes on in the following way: the concept of Evil God contains one imperfection (omnimalevolence) among all other perfections (except omnibenevolence), so this imperfection is something like a "black hole" in the plenitude of perfections. But perfections cannot exist separately: if we have some collection of perfections, we cannot simply add to them any property we please. Such a grave imperfection as omnimalevolence cannot exist in such a perfect surrounding, composed of so many perfections: it just doesn't fit them, they are metaphysically opposite and cannot coexist. But why should we agree with that? From an argument for the impossibility of Evil God we would normally expect to find something showing a reason why a certain property with some specific content is incompatible with some other properties with their specific contents, like in the case of the alleged incompatibility of omniscience with omnimalevolence. But here one is not appealing to the specific content of properties, only to some abstract features of those properties, like "being a perfection" and "being an imperfection" and some pretty vague and unclear intuitions of general incompatibility of perfections and imperfections.

To substantiate those intuitions, some theists appeal to certain ancient metaphysical doctrines, like the mediaeval doctrine of transcendentals, which identifies Being, Good, Beauty and Truth (and some other properties, like Unity) and has some antecedents in the Greek, especially Platonic, thought. But such an argument is endangered by circularity: the transcendental identification of Being with Good and Beauty is due to the assumption that every being is a creation of God, and everything which good God creates must be good and beautiful. The doctrine of transcendentals presupposes the existence of God, so using this doctrine to defend ontological arguments for the existence of God would beg the question. The claim that it is metaphysically impossible for an imperfection to exist among the plenitude of perfections slightly reminds of a "metaphysical" argument against the existence of sunspots, 
discovered by Galileo: Aristotelian opponents of the astronomer were a priori demonstrating that there can be no dark places on Sun, since Sun and light, by virtue of their "nature", exclude any darkness. In our case, Sun is the plenitude of perfections (except omnibenevolence) and sunspot is the imperfection of omnimalevolence. Some explanation for the intuitions of the incompatibility of omnimalevolence with the plenitude of almost all perfections may be the ambiguity of the notion of perfection, pointed to in earlier discussion. When we conceive "perfection" unambiguously, then we may be tempted to feel that the imperfection of omnimalevolence is somehow out of place in the plenitude of all perfections (except omnibenevolence). But after we realize the ambiguity, this impression should disappear.

Out of the popularly discussed divine attributes, the only perfection in the axiological sense is omnibenevolence, ${ }^{10}$ while all other attributes (like omnipotence, omniscience, necessary existence, etc.) are perfections in the neutral sense. So, when we subtract omnibenevolence from the set of all other perfections, we arrive at a concept containing purely neutral perfections, and since omnimalevolence is imperfection in the axiological sense, then there is no reason to suppose why it should be incompatible with them, since omnimalevolence and other properties are (im)perfections with respect to very different criteria. The impression of incompatibility was caused by overlooking the ambiguity.

Probably more arguments for the inconsistency of the concept of Evil God could be formulated. But, as we saw it in the case of two examples of such arguments, probably they would eventually be as inconclusive as well-known atheistic arguments that the concept of God is inconsistent, like the paradox of stone against omnipotence or the claim that omnipotence is inconsistent with omniscience. What I am trying to show is a relative consistency proof for the concept of Evil God. Relative consistency proofs are known from mathematical logic: for example, we cannot prove that Peano arithmetic is consistent, but we can prove that Peano arithmetic is consistent if Heyting arithmetic is consistent.

A slightly similar situation occurs here: we cannot prove that Evil God is possible, but if someone believes - without a proof - that God is possible, then he or she is in no position to say that Evil God is impossible, unless an explicit proof of impossibility is delivered. Somebody could

${ }^{10}$ One could also add infinite justice, infinite love, etc., but I think that those attributes can be treated as immanent parts of omnibenevolence. 
object that certain people, most notably Leibniz and Gödel, presented proofs of the consistency of the concept of God, so this concept has an advantage over the other ones. Those proofs are highly disputable, but this is not a proper place to go into any details. Apart from that, any proof of the consistency of the concept of God does not show that the concepts of quasi-Gods and Evil God are inconsistent. If we don't have proofs for the inconsistency of the concept of quasi-Gods and Evil God, then we have no reason to claim that those concepts are inconsistent, when there is no prima facie inconsistency in them. Many people, including many theists, claim that it is legitimate to assume the possibility of something as long as there is no explicit proof of its impossibility. This principle is sometimes used by supporters of ontological arguments to establish rational acceptability of the premise "God is possible". But this stick has two ends: we may use the same principle to establish rational acceptability of the analogous premises of possibility of the existence of quasi-Gods and Evil God.

\section{CONCLUSIONS}

Considerations about the inconsistency objection seem to show that eventually there is an epistemic equilibrium between modal ontological arguments for the existence of God and the existence of quasi-Gods and Evil God, and that adherents of the proofs for God cannot escape the acceptability of the proofs for pseudo-Gods on the grounds of their theories. But what does that conclusion really mean? Firstly, it has not been shown that the joint acceptance of the existence of these deities is inconsistent or false, and secondly, it has not been shown that modal ontological arguments for the existence of God contain any fallacies, whether formal or material. But, I hope, it has been shown that modal ontological arguments are, in a sense, incompatible with (mono)theism, the view that there is only one deity - God, because a theist, using modal ontological arguments, is unable to block undesired instances of those arguments, which prove the existence of other deities.

This result does not show that modal ontological arguments are fallacious, but it shows that almost all of their proponents (who are theists) cannot use such arguments, because it would lead to inconsistency within their views. Such a result may seem very weak and unsatisfactory: it may seem that to refute the ontological arguments is to show where and why they are wrong. But if it really is the case that ontological 
arguments are theistically unacceptable, it is a most important result, because it allows us to finish the discussion about ontological arguments and herald a victory for the opponents of those arguments. What is more, their supporters (assuming that the arguments outlined here shall convince them) will give up ontological arguments and help the others find where and why they are wrong. Recognition of the incompatibility of ontological arguments with (mono)theism is the first step in this inquiry, but it is sufficient to establish the generally negative attitude to ontological arguments.

Although this result is partial, it is much more beneficial than criticisms which aim at precise identification of fallacies of ontological arguments, but pay a high price for it: they are highly inconclusive, and therefore unable to establish an effective, general argument against ontological arguments. It is hard to decide whether modal ontological arguments are sound or not, but if my considerations are correct, then ontological arguments are useless in the role of establishing theistic beliefs - a role which those arguments were intended to play by almost all of its proponents.

If some manicheists, maltheists or even polytheists would happily employ ontological arguments to prove the existence of the multitude of deities they believe in, it could be not an easy task to show that they are wrong. We cannot show that modal ontological arguments are invalid or unsound, but we can show that they are dialectically ineffective, not merely by pointing to the obvious empirical fact that people usually aren't very impressed by them. And this is a sufficient reason to reject those arguments.

\section{BIBLIOGRAPHY}

Hartshorne, Charles. Anselm's Discovery: A Re-Examination of the Ontological Proof for God's Existence (La Salle: Open Court, 1991)

Malcolm, Norman. 'Anselm's Ontological Arguments', The Philosophical Review, 69 (1960), 41-62

Plantinga, Alvin. The Nature of Necessity (Oxford: Clarendon Press, 1978)

Woleński, Jan. 'Gaunilon dzisiaj', (Gaunilo Today) in Dowody ontologiczne. W 900. rocznice śmierci św. Anzelma, ed. Stanisław Wszołek (Kraków: Copernicus Center Press, 2011), pp. 21-34 